\title{
Heritability for Morphological Traits Determine Adaptability of Elite Cowpea Genotypes in different Environments
}

\author{
Joseph Nwafor Akanwe Asiwe ${ }^{1 *}$, Marry Molebjane Sekgobela ${ }^{1}$ and Patricia Phala Modiba ${ }^{2}$ \\ ${ }^{1}$ Department of Plant Production, Soil Science and Agricultural Engineering, University of Limpopo, Private Bag X1106, \\ Sovenga 0727, South Africa \\ ${ }^{2}$ Limpopo Department of Agriculture, Towoomba Research Station, Bela-Bela, South Africa \\ *For correspondence: joseph.asiwe@ul.ac.za; josephasiwe012@gmail.com \\ Received 06 August 2020; Accepted 04 January 2021; Published 10 June 2021
}

\begin{abstract}
Lack of improved and high-yielding adapted varieties constitutes limitation to cowpea (Vigna unguiculata (L.) Walp) production in South Africa. Therefore, field trials were conducted in two locations (the University of Limpopo Experimental Farm, (Mankweng) and Towoomba Research Station, Bela-Bela) during 2015-16 and 2016-17, to assess yield components, genotype $\mathrm{x}$ environment interaction as well as the adaptability of elite cowpea genotypes. The experiment was laid out using a randomized complete block design in three replications. Data were collected on flowering, maturity and yield components. Results revealed that "genotype, and genotype $\times$ year and genotype $\times$ location interactions were significant for most of the traits evaluated". 'The days to 50\% flowering' and '90\% maturity' ranged between 53 and 60 days, and between 89 and 96 days, respectively. The ' 100 -seed weight' varied from $15.8 \mathrm{~g}$ to $22.5 \mathrm{~g}$. 'Broad-sense heritability' varied from 0 to $93 \%$ for days to maturity and grain yield, respectively. 'Grain yield' varied from 1465.7 to $2594.9 \mathrm{~kg} \mathrm{ha}^{-1}$, and the best yielders were lines 'L2', 'L10', and 'L7'. The 'PC1' and 'PC2' explained $82.57 \%$ variation for maturity, $79.12 \%$ for the 'pods per plant', $83.78 \%$ for 'seeds per pod', $93.09 \%$ for ' 100 -seed weight' and $95.84 \%$ for 'grain yield'. Towoomba was a more productive location compared to Sykerfuil. Lines 'L2', 'L10', and 'L7' yielded very well in both locations and years. This implies that they are adapted and are recommended for registration and commercial release in the region. (C) 2021 Friends Science Publishers
\end{abstract}

Keywords: Environment; Heritability; Syferkuil; Towoomba; Vigna unguiculata; Yield

\section{Introduction}

Cowpea is an important grain legume because it is a major source of cheap dietary protein that nutritionally complements over depended low-protein staple cereals and potatoes in South Africa. The largest production of this crop is in sub-Saharan Africa, where it is a staple feed for animals (Tarawali et al. 1997). Cowpea can be prepared in different forms (boiled as pudding and soup, steamed as moin moin, fried as akara (Asiwe et al. 2020b) to meet the dietary needs of the consumers. Cowpea provides nutritious grain and an inexpensive source of plant protein for rural dwellers as the grain contains protein that ranges from 23 to 32\% (Hall 2012; Asiwe 2017) and 64\% carbohydrate (Bressani 1985). It is an important income earner to all the stakeholders in the value chain (Asiwe et al. 2020a, b; Asiwe and Maimela, 2020). It is commonly intercropped with cereal crops, such as maize (Zea mays L.), sorghum (Sorghum bicolor (L.) Moench) and proso millet (Panicum miliaceum L.) (Timko and Singh 2008; Belane et al. 2011), because it fixes atmospheric nitrogen in which the subsequent cereal crops in rotation benefit from the nitrogen fixed. Cowpea is commonly used as a companion crop in most legume-cereal intercropping system to reduce crop failure because it is drought tolerant. On the global scale, the annual production area is estimated to be 12,5 million hectares, with a total grain production of 3 million tons, although only a small proportion of this production enters international trade. In Africa, West and Central Africa are the leading cowpea-producers constituting about $64 \%$ of the global production.

Cowpea is believed to have originated from West and Southern Africa because both wild and cultivated species abound in these regions. The production of cowpea has since spread to East and central Africa, India, Asia, South and Central America. The highest genetic diversity of primitive wild species of cowpea is found in the Southern Africa (Namibia, Botswana, Zambia, Zimbabwe, Mozambique, Swaziland, and South Africa) (DAFF 2011). Padulosi (1993) indicated that the most primitive species of 
cowpea were observed in the Transvaal (which consists of Gauteng, Limpopo and Mpumalanga Provinces), Western Cape and Swaziland. In the past, the genetic diversity among cultivated varieties of cowpea were believed to be low, however, with use of marker-assisted selection and breeding, the genetic diversity among improved cowpea varieties has greatly improved (Adu 2018; Araújo et al. 2019; Nkhoma et al. 2020).

DAFF (2011) reported that small-scale farmers achieve cowpea production in South Africa under rain-fed farming conditions but there are no records regarding the size of area under production and yields produced. However, Asiwe (2009) reported that smallholder farmers cultivate land ranging between 0.5 to 2.0 hectares for cowpea. The major cowpea production areas in South Africa are Limpopo, Mpumalanga, North-West and KwaZulu-Natal (DAFF 2011) and obtainable yield ranges between 200-500 kg ha ${ }^{-1}$ which are mainly for home consumption and excess is sold as a source of family income.

Asiwe (2009) reported that research on cowpea has been neglected during the past several decades in South Africa because of the unavailability of funds from the government and lack of researchers interested in the improvement of this crop. This has caused growers to rely on local varieties that are low yielding. Lack of improved varieties for cultivation, lack of information on good agronomic practices, and discouraging poor marginal returns to farmers have been reported to be important constraints limiting cowpea production in South Africa (Asiwe 2009). These constraints point to the need for increasing cowpea yields in South Africa by developing superior genotypes that are high yielding and adapted to the climatic conditions of the country. Breeding cowpea cultivars with varying important economic traits have been reported to enhance cowpea cultivars to adapt or overcome biotic and abiotic stresses (Piebiep et al. 2017). Cowpea varieties that exhibit early maturity have also been reported to evade different forms of abiotic stress (Fatokun et al. 2012; Hall 2012).

Screening, selection, and on-farm testing of promising cowpea varieties for adaption are critical to the sustainability of food security and nutrition in South Africa, and this can be achieved by evaluating available elite cowpea lines in target locations. However, the identification of superior varieties in mega testing environments is confounded by 'genotype $\times$ environment interaction' (GEI) (Yan and Tinker 2006). GEI is defined as an inconsistent performance of genotypes across different environments (Zakir 2018). This confounds the evaluation of genotypes in many environments difficult because some genotypes may perform well in one environment but poor in another (Eberhart and Russell 1966; Sabaghnia 2015). According to Thillainathan and Fernandez (2002), cultivars that perform well across a wide range of testing locations and years are recommended and released. This can be achieved by evaluating the potentials of the genotypes in many locations and years (Asfaw et al. 2009).

Cowpea breeding program at the University of Limpopo has developed many promising breeding lines, but these lines have not been tested in multiple locations to assess their adaptation. This paper reports results obtained from the agronomic performance, 'genotype $\mathrm{x}$ environment interaction' (GEI) as well as the adaptation of 10 elite cowpea genotypes evaluated at two distinct locations (University of Limpopo Experimental Farm, Syferkuil, Mankweng and Towoomba Research Station, Bela-Bela) during two years (2015/2016 and 2016/2017).

\section{Materials and Methods}

\section{Description of the study area}

Field experiments were conducted in 2016 and 2017 at the University of Limpopo Experimental Farm ('Syferkuil') in 'Mankweng' (2351'S, 2942'E: $1250 \mathrm{~m}$ above sea level) and 'Towoomba' Research Station located in Bela-Bela

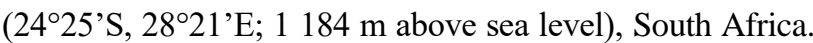
The soil at Syferkuil and Towoomba is sandy loam. The mean average summer day temperature at Syferkuil varies from $28^{\circ} \mathrm{C}$ to $30^{\circ} \mathrm{C}$, and the area receives annual rainfall ranging from 400 to $600 \mathrm{~mm}$. Towoomba receives $630 \mathrm{~mm}$ of rainfall, with the rainy season usually extending from October to March, but rainfall frequency is poor, erratic, and unpredictable (Fig. 1). The summer temperature ranges from $17.6^{\circ} \mathrm{C}$ to $30.2^{\circ} \mathrm{C}$. Both locations are approximately $200 \mathrm{~km}$ apart.

\section{Experimental materials}

The 10 elite lines were selected from the advanced and fixed progeny population in the cowpea breeding program. The descriptions of the lines are shown in Table 1. The genotypes were bred and selected for disease resistance to enhance their adaptation and adoption by farmers.

\section{Treatments}

The trial was conducted with a randomized complete block design in three replications. The trials were conducted during two years (2015/16 and 2016/17) at two distinct locations (University of Limpopo Experimental Farm, Syferkuil, Mankweng, and Towoomba Research Station, 'Bela-Bela') representing four environments. The ten elite cowpea breeding lines ('L1-L10') and a check variety, 'Bechuana white' ('BW') (Table 1) were manually planted at an inter-row and intra-row spacing of $1 \mathrm{~m}$ and $0.3 \mathrm{~m}$, respectively, in four rows of $3 \mathrm{~m}$ length each.

\section{Crop management}

Weeds were controlled by spraying a mixture of Roundup® and Dual ${ }^{\circledR}$ at the rate of three litres per hectare, and a half 
Table 1: The morphology description of cowpea lines used in the study

\begin{tabular}{|c|c|c|c|c|c|c|}
\hline Genotype & Growth habit & 100-seed weight $(\mathrm{g})$ & Seed size & Coat colour & Eye colour & Coat texture \\
\hline L1 & Erect & 20.46 & Large & White & Black & Wrinkled \\
\hline L2 & Prostrate & 18.30 & Large & White & Black & Wrinkled \\
\hline L3 & Prostrate & 18.61 & Large & White & Brown & Wrinkled \\
\hline $\mathrm{L} 4$ & Erect & 22.70 & Large & White & Black & Rough \\
\hline L5 & Erect & 18.60 & Large & Cream & Brown & Smooth \\
\hline L6 & Prostrate & 20.52 & Large & Brown & Brown & Smooth \\
\hline L7 & Erect & 22.08 & Large & White & Black & Smooth \\
\hline L8 & Erect & 19.28 & Large & Brown & Black & Rough \\
\hline L9 & Erect & 19.39 & Large & White & Black & Rough \\
\hline L10 & Prostrate & 21.86 & Large & White & Brown & Wrinkled \\
\hline BW (Check variety) & Semi-erect & 15.67 & Medium & White & Grey & Smooth \\
\hline
\end{tabular}

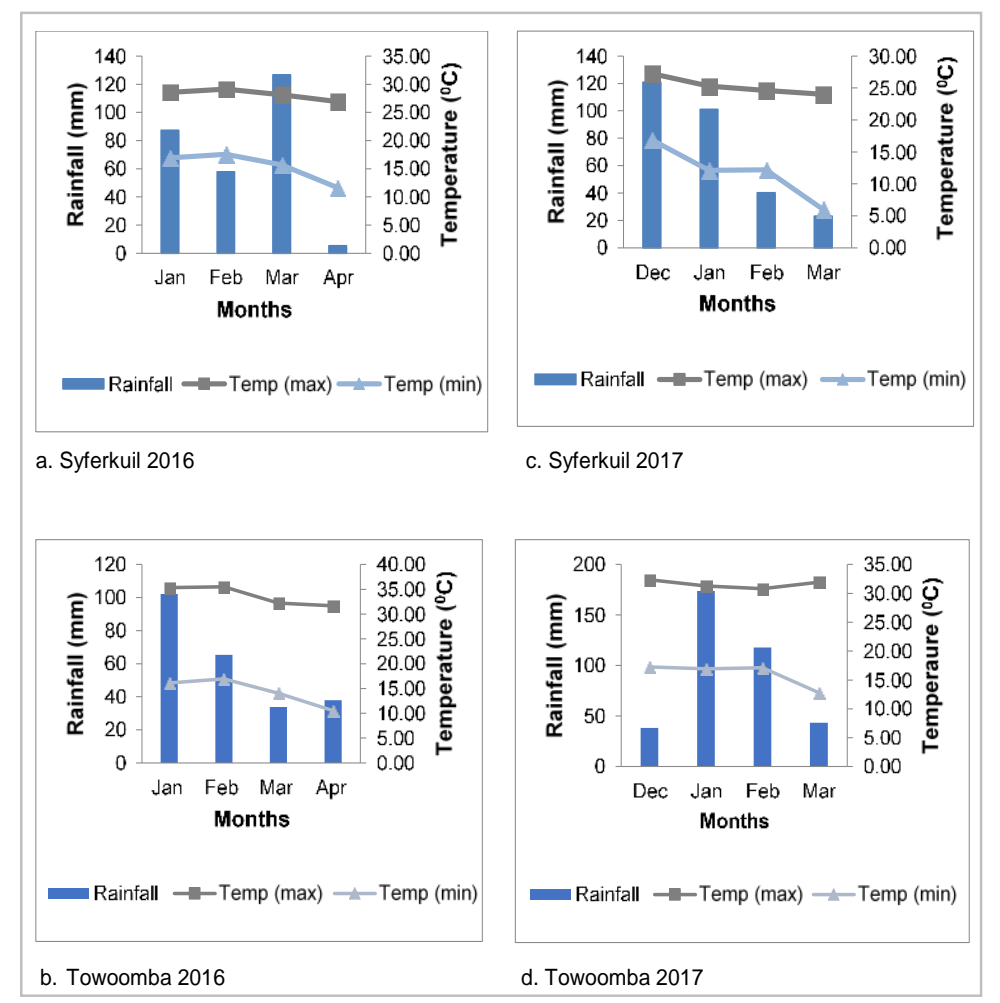

Source: Agricultural Research Council - ISCW and University of Limpopo weather station records

Fig. 1: (a-d): Mean monthly rainfall, minimum and maximum temperatures during the growing seasons at Syferkuil and Towoomba

litre per hectare, respectively, immediately after planting to control weeds. During crop growth, manual weeding was done when necessary. Insecticide, Karate ${ }^{\circledR}$ was sprayed at the rate of a litre per hectare at seedling, flowering and podding stages to control aphids, pod borers, and other insects. The Vine separation was done before flowering to avoid intertwining of genotypes and to facilitate harvesting of pure stands. Given the level of phosphorous and potassium indicated by a routine soil test, no fertilizers were applied. This was done to simulate farmers' cultural practices where farmers depend on the residual $\mathrm{P}$ and $\mathrm{K}$ from previous fertilization of the preceding maize crop.

\section{Data collection}

To assess the performance of the cowpea genotypes, the following agronomic data were collected, 'days to $50 \%$ flowering', 'days to $90 \%$ maturity' and pods from five plants were sampled randomly and expressed as 'pods per plant', 'seeds per pod' was also determined from the five pods. The ' 100 -seed weight' was determined by weighing 100 randomly selected seeds per genotype.

Monthly rainfall and temperature for the two locations and years were obtained from the University of Limpopo Experimental Farm weather records (Syferkuil) in Mankweng and Agricultural Research Council-Institute for 
Soil, Climate and Water (Pretoria).

\section{Plant harvesting}

At maturity, grain yield was assessed from two middle rows (net plot) by weighing the grains shelled from each net plot using a measuring scale, and this was converted into $\mathrm{kg} / \mathrm{ha}$ using the formula:

Grain yield $=\left(\left(\right.\right.$ Grain weight $(\mathrm{kg}) /\left(\right.$ Area harvested $\left.\left.\left(\mathrm{m}^{2}\right)\right)\right) \times 10000 \mathrm{~m}^{2}$

\section{Data analysis}

Analysis was conducted based on the "general linear model" (GLM) procedure of "SAS software" (SAS Institute Inc. 2013, 9.4 Edition) to determine the performance of different genotypes across locations and years, as well as to determine ' $\mathrm{G} \times \mathrm{E}$ interaction'. Means separation of traits that showed significant differences were achieved by using the 'Duncan's Multiple Range Test' at a 5\% significant level. Estimates of genetic variability and heritability for all the traits were estimated using the formulae reported by Comstock and Robinson (1952), and as follows:

$$
\begin{gathered}
\text { "Environmental variance }(\sigma 2 \mathrm{e})=\mathrm{MSe} \\
\text { Genotypic variance }(\sigma 2 \mathrm{~g})=(\mathrm{MSg}-\mathrm{Msgy}-\mathrm{MSgl}+\mathrm{MSgyl}) / \mathrm{ryl} \\
\text { Variance due to genotype } \times \text { year }(\sigma 2 \mathrm{gy})=(\mathrm{MSgy}-\mathrm{MSe}) / \mathrm{rl} \\
\text { Variance due to genotype } \times \text { location }(\sigma 2 \mathrm{gl})=(\mathrm{MSgl}-\mathrm{MSgyl}) / \mathrm{ry} \\
\text { Variance due to genotype } \times \text { year } \times \text { location }(\sigma 2 \mathrm{gyl})= \\
(\mathrm{MSgyl}-\mathrm{MSe}) / \mathrm{r} \\
\text { Phenotypic variance }(\sigma 2 \mathrm{p})=\sigma 2 \mathrm{~g}+(\sigma 2 \mathrm{gy} / \mathrm{y})+(\sigma 2 \mathrm{gl} / \mathrm{y})+ \\
(\sigma 2 \mathrm{gyl} / \mathrm{yl})+(\sigma 2 \mathrm{e} / \mathrm{ryl})
\end{gathered}
$$

where ' $y$ is the number of years, 1 is the number of locations, $\mathrm{r}$ is the number of replications, MSg, MSgy, MSgl, MSgyl, and MSe are the means squares for the genotype, $\mathrm{G} \times \mathrm{Y}$, $\mathrm{G} \times \mathrm{L}, \mathrm{G} \times \mathrm{Y} \times \mathrm{L}$ interactions and error', respectively".

The estimation of broad-sense heritability was achieved using the following formula:

$$
\text { ' } \mathrm{H} 2 \mathrm{~b}=(\sigma 2 \mathrm{~g} / \sigma 2 \mathrm{p}) \times 100 '
$$

Robinson et al. (1949), and Fehr (1987) categorized heritability as, "low" (0-30\%), "moderate" (31-60\%) and "high" (61\% and "above".

\section{Results}

\section{Weather information}

The total rainfall during the growing period at Syferkuil was between 277 and $285 \mathrm{~mm}$ in 2016 and 2017, respectively (Figs. 1 a and c), compared to Towoomba, which ranged between 239 and $373 \mathrm{~mm}$, respectively (Figs. $1 \mathrm{~b}$ and d). In 2016, most of the rainfall occurred in March at Syferkuil, compared to Towoomba which occurred in January. During 2017, the rainfall peaked in December at Syferkuil, and at
Towoomba, it was in January. The rainfall declined through February until March (Figs. 1 a-d). Temperature at Towoomba was hotter compared to Syferkuil during both years, and in 2016, temperature was hotter than in 2017 (Figs. $1 \mathrm{a}-\mathrm{d}$ ).

\section{Performance of varieties}

The results show that a significant $(P \leq 0.05)$ difference was obtained on the main effects (genotypes and years) for most of the variables measured (Table 2). A significant difference was also observed for location in the 'days to $50 \%$ flowering' 'seeds per pod' and 'grain yield' (Table 2). Interactions between genotype and year $(\mathrm{G} \times \mathrm{Y})$, genotype by location $(\mathrm{G} \times \mathrm{L})$, year by location $(\mathrm{Y} \times \mathrm{L})$ and genotype by year by location $(\mathrm{G} \times \mathrm{Y} \times \mathrm{L})$ were significant $(P \leq 0.05)$ for several variables (Table 2). Across locations and years, line 'L9' flowered earlier than all the genotypes including local check BW. Late flowering was exhibited by line 'L7' (Table 3). The genotypes took relatively longer (96 days at both locations) to attain maturity in 2017 (Table 3). Line L7 and 'L3' did not express consistency in days to attain 'maturity' during both years and locations. Line L9 was the earliest to mature, followed by line 'L2'. Significant variation $(P \leq 0.05)$ were observed among genotypes for pods per plant, and interactions between ' $\mathrm{L} \times \mathrm{Y}$ ', ' $\mathrm{G} \times \mathrm{L}$ ' and ' $\mathrm{G} \times \mathrm{Y} \times \mathrm{L}$ ' were significant. ' $\mathrm{G} \times \mathrm{Y} \times \mathrm{L}$ ' interaction was also significant $(P \leq 0.05)$ for the 100 -seed weight (Table 4). A higher 'pods per plant' was observed at Towoomba in 2017 compared to Syferkuil with mean values of 25.6 and 16.6 pods per plant, respectively. Significant variation $(P \leq 0.05)$ was observed for genotypes, years, locations, and $\mathrm{L} \times \mathrm{Y}$ interaction for the 'gran yield' (Table 5). A higher grain yield (above $1500 \mathrm{~kg} \mathrm{ha}^{-1}$ ) was recorded at Towoomba in 2017, with a mean of $2093.0 \mathrm{~kg}$ $\mathrm{ha}^{-1}$, compared to Syferkuil that produced $1255.8 \mathrm{~kg} \mathrm{ha}^{-1}$. Low broad-sense heritability was observed for days to $90 \%$ maturity, days to $50 \%$ flowering and pods per plant. However, high heritability was observed for the number of seeds per pod, 100-seed weight, and grain yield (Table 6).

The "which-won-where" and 'mega-environment' identifications were graphically visualized through 'GGE' 'biplot' (Fig. 2 a-f), using 'environment-centered' (centering $=2$ ) and environment metric preserving (SVP = 2) model for the following traits, 'days to $50 \%$ flowering', 'days to $90 \%$ maturity', 'pods per plant', 'seeds in a pod', '100-seed weight' and 'grain yield'. The two 'principal components' ('PC1' and 'PC2') explained $93.51 \%$ of the total sum of square variation for days to $50 \%$ flowering, $82.57 \%$ of the variation for days to ' $90 \%$ maturity', $79.12 \%$ for ' pods per plant', $83.78 \%$ for seeds per pod, $93.09 \%$ for the 100 -seed weight and $95.84 \%$ for the grain yield. In the "which-won-where" biplot, the environments were distributed by equality lines into different sectors for days to flowering (3), for days to maturity (4), pods per plant (6), seed per pod (6), 100-seed weight (6), and grain yield (5) 
Adaptation of Cowpea Varieties in Limpopo Province / Intl J Agric Biol, Vol 26, No 1, 2021

Table 2: Mean squares for days to flowering, days to maturity, pods per plant, seeds per pod, 100-seed weight and grain yield of 11 cowpea genotypes grown at two locations and two years

\begin{tabular}{|c|c|c|c|c|c|c|c|}
\hline \multirow[t]{2}{*}{ Source of variation } & d.f. & Days to flowering & Days to maturity & Pods per plant & Seeds per pod & 100 seed weight & Grain yield \\
\hline & & \multicolumn{6}{|c|}{ Mean squares } \\
\hline Reps & 2 & 0.945 & 2.27 & 21.07 & 3.274 & 16.617 & 133198 \\
\hline Year (Y) & 1 & $144.273^{* *}$ & $807.59 * *$ & $623.86 * *$ & $26.371 * *$ & $51.394 * *$ & $495396^{*}$ \\
\hline Location (L) & 1 & $56.03 * *$ & $10.09 \mathrm{~ns}$ & $13.64 \mathrm{~ns}$ & $81.31 * *$ & $7.995 \mathrm{~ns}$ & $4731182^{* *}$ \\
\hline $\mathrm{Y} \times \mathrm{L}$ & 1 & $88.364 * *$ & $12.43 \mathrm{~ns}$ & $1007.99 * *$ & $52.441 * *$ & $0.001 \mathrm{~ns}$ & $11277017 * *$ \\
\hline Genotype (G) & 10 & $45.131 * *$ & $56.17 * *$ & $78.77 \mathrm{~ns}$ & $7.612 * *$ & $48.901 * *$ & $1128238 * *$ \\
\hline $\mathrm{G} \times \mathrm{Y}$ & 10 & $34.064 * *$ & $44.67 * *$ & $105.77^{*}$ & $1.814 \mathrm{~ns}$ & $4.622 \mathrm{~ns}$ & $54961 \mathrm{~ns}$ \\
\hline $\mathrm{G} \times \mathrm{L}$ & 10 & $10.689 * *$ & $33.47 * *$ & $58.21 \mathrm{~ns}$ & $2.877 \mathrm{~ns}$ & $2.972 \mathrm{~ns}$ & 22936ns \\
\hline $\mathrm{G} \times \mathrm{Y} \times \mathrm{L}$ & 10 & $8.355^{*}$ & $9.91 \mathrm{~ns}$ & $123.25^{* *}$ & $1.862 \mathrm{~ns}$ & $7.584^{*}$ & 91222ns \\
\hline Error term & 86 & 3.635 & 11.08 & 46.93 & 1.801 & 3.696 & 88123 \\
\hline Total & 131 & & & & & & \\
\hline
\end{tabular}

Table 3: Mean days to 50\% flowering and 90\% maturity of 11 cowpea genotypes evaluated across four environments $\uparrow$ (two locations and two years)

\begin{tabular}{|c|c|c|c|c|c|c|c|c|c|c|}
\hline \multirow[t]{3}{*}{ Genotype } & \multicolumn{4}{|c|}{ Days to flowering } & \multicolumn{6}{|c|}{ Days to maturity } \\
\hline & \multicolumn{2}{|c|}{$\begin{array}{c}\text { Syferkuil } \\
\end{array}$} & \multicolumn{2}{|c|}{ Towoomba } & \multicolumn{3}{|c|}{ Syferkuil } & \multicolumn{2}{|c|}{ Towoomba } & \multirow[b]{2}{*}{ Mean } \\
\hline & 2016 & 2017 & 2016 & 2017 & Mean & 2016 & 2017 & 2016 & 2017 & \\
\hline L1 & 54 & 56 & 54 & 53 & 54de & 89 & 98 & 90 & 100 & $94 a$ \\
\hline L3 & 55 & 63 & 54 & 52 & $56 c$ & 97 & 102 & 88 & 96 & $96 a$ \\
\hline $\mathrm{L} 4$ & 53 & 56 & 54 & 52 & 54de & 87 & 96 & 91 & 97 & $93 \mathrm{ab}$ \\
\hline L5 & 54 & 58 & 54 & 55 & $55 \mathrm{~cd}$ & 95 & 95 & 95 & 94 & $95 a$ \\
\hline L6 & 54 & 58 & 55 & 53 & $55 \mathrm{~cd}$ & 90 & 98 & 92 & 99 & $95 \mathrm{a}$ \\
\hline L7 & 54 & 64 & 56 & 65 & $60 \mathrm{a}$ & 96 & 95 & 100 & 94 & $96 a$ \\
\hline L8 & 53 & 57 & 55 & 57 & $55 \mathrm{~cd}$ & 92 & 99 & 92 & 98 & $95 \mathrm{a}$ \\
\hline L9 & 57 & 51 & 54 & 51 & $53 \mathrm{e}$ & 85 & 91 & 85 & 95 & $89 c$ \\
\hline $\mathrm{L} 10$ & 53 & 56 & 55 & 52 & 54de & 92 & 98 & 89 & 97 & $94 a$ \\
\hline BW (Check variety) & 55 & 61 & 56 & 60 & $58 b$ & 89 & 95 & 99 & 97 & $95 \mathrm{a}$ \\
\hline Mean & 54 & 58 & 54 & 55 & 55 & 91 & 96 & 92 & 96 & 94 \\
\hline
\end{tabular}

${ }^{\dagger}$ Means followed by the same letters in each column do not differ significantly at $P \leq 0.05$

Table 4: Mean pods per plant and seeds per pod of 11 cowpea genotypes evaluated across four environments $\dagger$ (two locations and two years)

\begin{tabular}{|c|c|c|c|c|c|c|c|c|c|c|}
\hline \multirow[t]{3}{*}{ Genotype } & \multicolumn{5}{|c|}{ Pods per plant } & \multicolumn{4}{|c|}{ Seeds per pod } & \multirow[b]{3}{*}{ Mean } \\
\hline & \multicolumn{2}{|c|}{ Syferkuil } & \multicolumn{3}{|c|}{ Towoomba } & \multicolumn{2}{|c|}{ Syferkuil } & \multicolumn{2}{|c|}{ Towoomba } & \\
\hline & 2016 & 2017 & 2016 & 2017 & Mean & 2016 & 2017 & 2016 & 2017 & \\
\hline L1 & 29.3 & 17.1 & 21.8 & 20.0 & $22.0 \mathrm{ab}$ & 11.6 & 8.6 & 11.9 & 13.9 & $11.5 b c$ \\
\hline $\mathrm{L} 2$ & 18.7 & 17.8 & 30.6 & 20.6 & 21.9ab & 11.4 & 9.3 & 11.2 & 11.8 & $10.9 \mathrm{~cd}$ \\
\hline L3 & 11.0 & 9.0 & 16.5 & 27.4 & $16.0 \mathrm{~b}$ & 12.5 & 9.6 & 11.9 & 13.4 & $11.8 \mathrm{a}-\mathrm{c}$ \\
\hline $\mathrm{L} 4$ & 28.2 & 24.3 & 20.8 & 25.8 & $24.8 \mathrm{ab}$ & 11.1 & 10.3 & 10.3 & 11.1 & $10.7 \mathrm{~cd}$ \\
\hline L5 & 28.1 & 9.2 & 10.7 & 29.2 & $19.3 \mathrm{ab}$ & 12.5 & 9.5 & 14.1 & 13.2 & $12.3 \mathrm{ab}$ \\
\hline L6 & 19.9 & 22.0 & 18.0 & 22.9 & $20.7 \mathrm{ab}$ & 12.1 & 8.2 & 11.7 & 11.1 & $10.8 \mathrm{~cd}$ \\
\hline L7 & 16.9 & 22.2 & 28.2 & 31.6 & $25.5 \mathrm{a}$ & 11.5 & 9.1 & 12.4 & 12.8 & $11.4 \mathrm{bc}$ \\
\hline L8 & 33.1 & 10.1 & 17.6 & 23.5 & $21.1 \mathrm{ab}$ & 10.7 & 8.9 & 10.8 & 10.2 & $10.2 \mathrm{~d}$ \\
\hline L9 & 15.8 & 15.0 & 15.2 & 23.4 & $17.4 \mathrm{ab}$ & 10.6 & 9.4 & 13.1 & 12.3 & $11.4 \mathrm{~b}-\mathrm{d}$ \\
\hline $\mathrm{L} 10$ & 21.5 & 15.8 & 22.9 & 29.1 & $22.3 \mathrm{ab}$ & 11.3 & 8.4 & 11 & 12.1 & $10.7 \mathrm{~cd}$ \\
\hline BW (Check variety) & 18.3 & 19.9 & 27.3 & 28.1 & $23.4 \mathrm{ab}$ & 12.5 & 12.9 & 12.8 & 13.4 & $12.9 \mathrm{a}$ \\
\hline Mean & 21.9 & 16.6 & 20.9 & 25.6 & 21.3 & 11.6 & 9.5 & 11.9 & 12.3 & 11.3 \\
\hline
\end{tabular}

\$Means followed by the same letters in each column do not differ significantly at $P \leq 0.05$

(Fig. 2a-f). The test environments fell into two of the three sectors outlined in the polygon (Fig. 2a). E1 (Syferkuil 2016) formed 'mega-environment 1' with line L9 being the vertex genotype. 'Environments E2' (Towoomba 2016), E3 (Syferkuil 2017), and E4 (Towoomba 2017) formed 'megaenvironments' 2, with line L7 as the 'vertex genotype'. For days to maturity (Fig. 2b), the test environments subset into two of the four sectors. 'E1', 'E3', and 'E4' were grouped to form mega-environment 1 , with the vertex genotype L3, showing that it matured late in those three environments. The check variety (BW) and L7 were the vertex genotypes in mega-environment 2 . For pods per plant, three megaenvironments were formed (Fig. 2c). The 'vertex genotype' was L8 in mega-environment 1 (E1). In the megaenvironment 2 ('E2', 'E3'), L7 was the vertex line and in mega-environment 3 (E4), L7 was the vertex line which shows that these lines had a high pods per plant in their associated mega-environments. In the case of seeds per pod, 

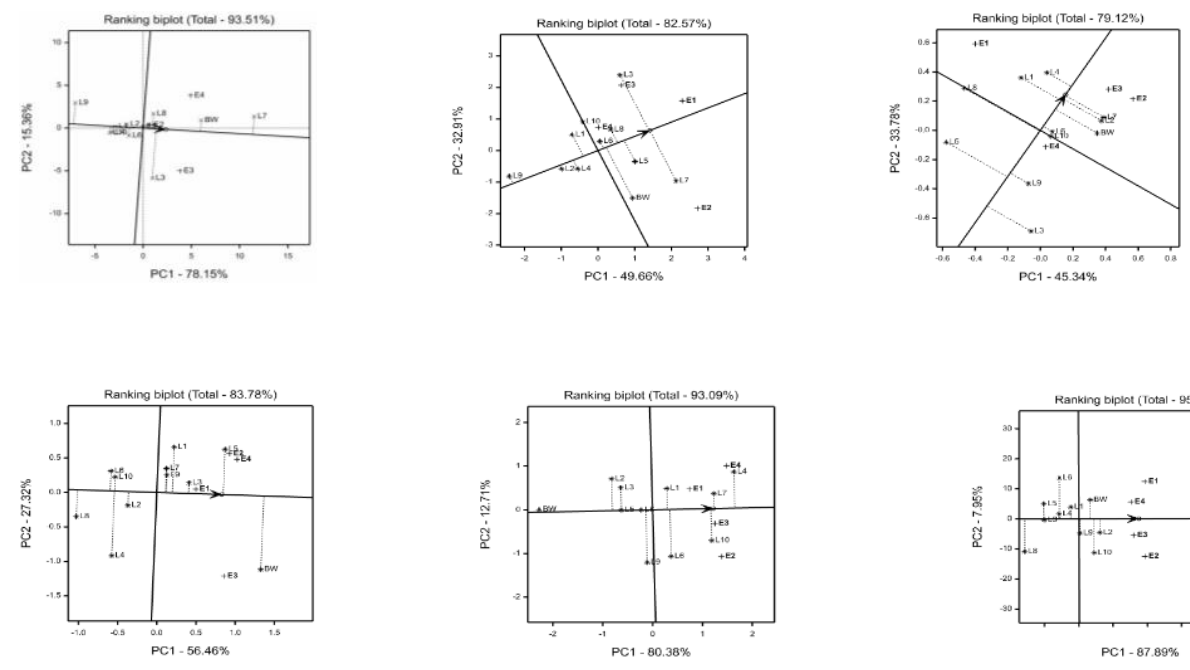

d. GGE biplot for seeds per

pod

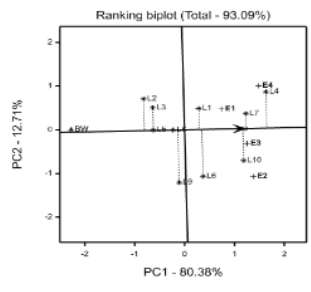

e. GGE biplot for hundred seed weight

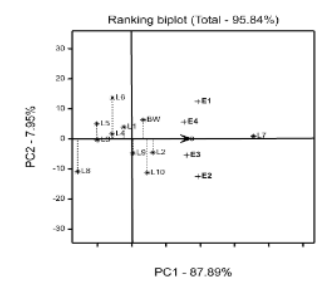

f. GGE biplot for grain yield

*Environments: E1= Syferkuil 2016, E2= Towoomba 2016, E3= Syferkuil 2017 and E4= Towoomba 2017; Genotypes: L1-L10, BW

Fig. 3: GGE biplot of mean yield performance and stability for (a) days to flowering, (b) days to maturity, (c) pods per plant, (d) seed per pod, (e) hundred seed weight and (f) grain yield of eleven tested cowpea genotypes across four environments

two mega-environments were formed (Fig. 2d). E2 and E4 occupied a sector to form mega-environment 1 , with line 'L5' being the vertex genotype. E1 and E3 formed megaenvironment 2, with $\mathrm{BW}$ being the vertex genotype. Two mega-environments were formed for 100 -seed weight. E1, $\mathrm{E} 3$, and $\mathrm{E} 4$ formed mega-environment 1. E2 formed megaenvironment 2 (Fig. 2e). The lines 'L1', L7, and 'L4' were associated with mega-environment 1 , with line $\mathrm{L} 4$ at the vertex. Line L10 was the vertex genotype in megaenvironment 2; this reveals that this genotype recorded the highest 100-seed weight in this environment, and the lowest 100 -seed weight in all other environments. For grain yield, all the test environments fell into one of the five sectors outlined in the polygon view; thus, one mega-environment was formed (Fig. 2f). Line L7 was the vertex genotype in that mega-environment, with mean values of 2831.7, 2556.7, 2051.3, and $2939.7 \mathrm{~kg} \mathrm{ha}^{-1}$ in E1, E2, E3, and E4, respectively (Table 6).

The direction of the higher mean performance of the genotypes is indicated by 'arrow on the abscissa' (Fig. 3 af). For days to $50 \%$ flowering lines L9, L1, L2, L10, and L6 were the earliest to attain $50 \%$ flowering. Lines L3, 'L6', and 'L9' produced a low pods per plant across the environments, and are placed on the left side of 'GGE biplot', which represents below-average performance (Fig. 3 c). BW and other lines were placed on the right-side of the biplot. For seeds in a pod, the lines that produced fewer pods were 'L8', 'L6', 'L10', 'L4', and 'L2'. All other lines, including 'BW' that ranked first, produced a relatively higher seeds per pod. For 100-seed weight, BW, L2, L3, L5 L8, and L9 exhibited 'below-average performance' whereas L1, L6, L10, L7, and L4 produced the highest 100-seed weight which was greater than the environment mean. The biplot for grain yield placed lines L8, L5, L3, L6, L4, and $\mathrm{L} 1$ on the left-side, categorizing their performance as belowaverage. The lines that achieved 'above-average performance' were BW, L10, L2, and L7 in increasing order.

\section{Discussion}

This study has demonstrated that there were significant genotype and environment interaction which influenced the performance of the lines. These results revealed that there was a differential yield performance among cowpea genotypes across the tested environments due to the presence of GEI. Significant variation in days flowering and physiological maturity of the lines suggest that the lines had adequate genetic variability which could be due to varietal characteristics in their determinacy. In this study, across locations and years was observed, lines L2 and L9 flowered earlier than all the genotypes which imply that these varieties (L9 and L2) have the capability of evading early frost, winter, and reduce risk of yield loss. According to Piebiep et al. (2017), the extra-early erect cultivars that exhibit synchronous flowering and early maturity are important economic traits preferred by farmers which enable the crop to evade terminal drought. The early maturing varieties provide useful food security during the hungry period. However, varieties that mature late can be considered for locations with a longer period of rainfall or be deployed for recurrent selection programs for further improvement. According to Jadhav et al. (1991), Summerfield (1980) and Owusu et al. (2018), warmer temperature is an important environmental condition for early flower production in cowpea. Since the temperature at 
Adaptation of Cowpea Varieties in Limpopo Province / Intl J Agric Biol, Vol 26, No 1, 2021

Table 5: Mean 100-seed weight and grain yield of 11 cowpea genotypes evaluated across four environments $\uparrow$ (two locations and two years)

\begin{tabular}{|c|c|c|c|c|c|c|c|c|c|c|}
\hline \multirow[t]{3}{*}{ Genotypes } & \multicolumn{4}{|c|}{ 100-seed weight (g) } & \multicolumn{6}{|c|}{ Grain yield $\left(\mathrm{kg} \mathrm{ha}^{-1}\right)$} \\
\hline & \multicolumn{2}{|c|}{ Syferkuil } & \multicolumn{2}{|c|}{ Towoomba } & \multirow[b]{2}{*}{ Mean } & \multicolumn{2}{|c|}{ Syferkuil } & \multicolumn{2}{|c|}{ Towoomba } & \multirow[b]{2}{*}{ Mean } \\
\hline & 2016 & 2017 & 2016 & 2017 & & 2016 & 2017 & 2016 & 2017 & \\
\hline L1 & 20.7 & 19.8 & 19.6 & 21.9 & $20.5 b c$ & 1842.3 & 1051 & 1760.3 & 2051.3 & $1676.2 b c$ \\
\hline L3 & 17.3 & 19.5 & 16.9 & 20.3 & $18.5 \mathrm{~cd}$ & 1721.3 & 1104 & 1803.7 & 1541.7 & $1542.7 \mathrm{~cd}$ \\
\hline $\mathrm{L} 4$ & 20.1 & 22.4 & 21.6 & 25.9 & $22.5 \mathrm{a}$ & 1542.3 & 1235 & 1479 & 2199 & $1613.8 b-d$ \\
\hline L5 & 17.4 & 20.5 & 17.2 & 18.9 & $18.5 \mathrm{~cd}$ & 1815.5 & 992.7 & 1427.3 & 1784.3 & $1505.0 \mathrm{~cd}$ \\
\hline L7 & 20.9 & 23.0 & 20.9 & 23.6 & $22.1 \mathrm{ab}$ & 2831.7 & 2051.3 & 2556.7 & 2939.7 & $2594.9 \mathrm{a}$ \\
\hline L8 & 18.6 & 19.0 & 19.3 & 19.9 & $19.2 \mathrm{~cd}$ & 1341.3 & 1116.3 & 1693 & 1712.3 & $1465.7 d$ \\
\hline L9 & 16.6 & 20.9 & 20.9 & 19.1 & $19.4 \mathrm{~cd}$ & 1352.7 & 1329.7 & 2081 & 1937.3 & $1675.2 b c$ \\
\hline L10 & 19.6 & 22.1 & 23.3 & 22.4 & $21.9 \mathrm{ab}$ & 1757.7 & 1446 & 2087.7 & 2240.7 & $1883.0 \mathrm{~b}$ \\
\hline BW (check variety) & 17.3 & 15.1 & 15.2 & 15.6 & $15.8 \mathrm{e}$ & 2364.3 & 1025.7 & 1841.3 & 2230.3 & $1865.4 b$ \\
\hline Mean & 18.7 & 20.2 & 19.4 & 20.7 & 19.7 & 1872 & 1255.8 & 1837.1 & 2093 & 1764.5 \\
\hline
\end{tabular}

¥Means followed by the same letters in each column do not differ significantly at $P \leq 0.05$

Table 6: Broad sense heritability estimate of days to $50 \%$ flowering, days to $90 \%$ maturity, pods per plant, seeds per pod, 100 -seed weight and grain yield of 11 cowpea genotypes evaluated across four environments

\begin{tabular}{|c|c|c|c|c|c|c|c|c|c|c|c|c|c|}
\hline Traits & Grand Mean & MSe & $\mathrm{MSg}$ & MSgy & $\mathrm{MSgl}$ & MSgyl & $\sigma^{2} \mathrm{e}$ & $\sigma^{2} \mathrm{~g}$ & $\sigma^{2} \mathrm{gy}$ & $\sigma^{2} \mathrm{gl}$ & $\sigma^{2}$ gyl & $\sigma^{2} p$ & $\mathrm{H}^{2} \mathrm{~b}$ \\
\hline $50 \% \mathrm{~F}$ & 55 & 3.64 & 45.13 & 34.06 & 10.69 & 8.36 & 3.64 & 0.73 & 4.28 & 0.39 & 1.57 & 3.76 & 19 \\
\hline $90 \% \mathrm{M}$ & 94 & 11.08 & 56.17 & 44.67 & 33.47 & 9.91 & 11.08 & 0 & 5.79 & 3.93 & 0.00 & 5.78 & 0 \\
\hline $\mathrm{P} / \mathrm{P}$ & 21.3 & 46.93 & 78.77 & 105.77 & 58.21 & 123.25 & 46.93 & 3.17 & 0 & 0 & 25.44 & 13.44 & 24 \\
\hline $\mathrm{S} / \mathrm{P}$ & 11.3 & 1.80 & 7.61 & 1.81 & 2.88 & 1.86 & 1.80 & 0.40 & 0 & 0.17 & 0.02 & 0.64 & 62 \\
\hline HSW & 19.7 & 3.70 & 48.90 & 4.62 & 2.97 & 7.58 & 3.70 & 4.07 & 0 & 0 & 1.30 & 4.71 & 87 \\
\hline GY & 1764.5 & 88123.00 & 1128238.00 & 54961.00 & 22936.00 & 91222.00 & 88123.00 & 95130.25 & 0 & 0 & 1033.00 & 102732.08 & 93 \\
\hline
\end{tabular}

$\dagger \mathrm{MSg}=$ genotype mean square, $\mathrm{MSe}=$ error mean square, $\mathrm{MSgy}=\mathrm{G} \times \mathrm{Y}$ interaction mean square, $\mathrm{MSgl}=\mathrm{G} \times \mathrm{L}$ interaction mean square, $\mathrm{MSgly}=\mathrm{G} \times \mathrm{Y} \times \mathrm{L}$ mean square, $\sigma^{2} \mathrm{e}=$ environmental variance, $\sigma^{2} \mathrm{~g}=$ genotypic variance, $\sigma^{2} \mathrm{gy}=$ variance due to $\mathrm{G} \times \mathrm{Y}$ interaction, $\sigma^{2} \mathrm{gl}=$ variance due to $\mathrm{G} \times \mathrm{L}$ interaction, $\sigma^{2} \mathrm{gyl}=$ variance due to $\mathrm{G} \times \mathrm{Y} \times \mathrm{L}$ interaction, $\sigma^{2} \mathrm{p}=$ phenotypic variance, $\mathrm{H}^{2} \mathrm{~b}=$ broad sense heritability. $50 \% \mathrm{~F}=$ days to $50 \%$ flowering, $90 \% \mathrm{M}=$ days to $90 \%$ maturity, $\mathrm{P} / \mathrm{P}=$ pods per plant, $\mathrm{S} / \mathrm{P}=$ seeds per pod, $\mathrm{HSW}=100-$ seed weight, GY = grain yield
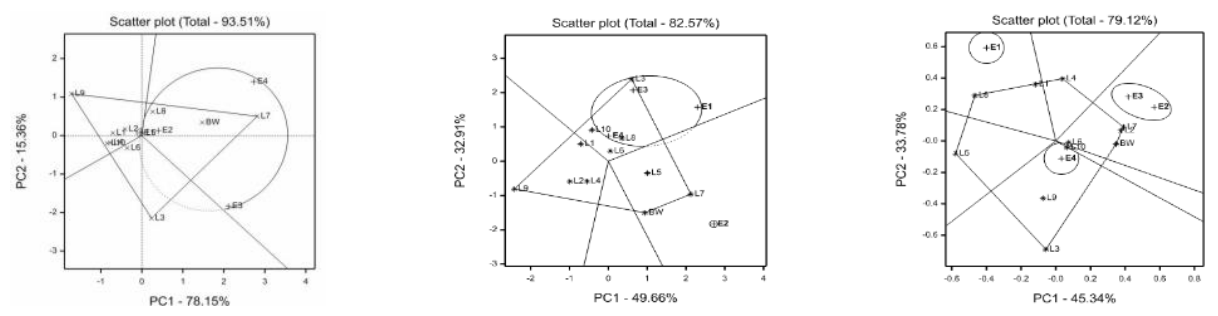

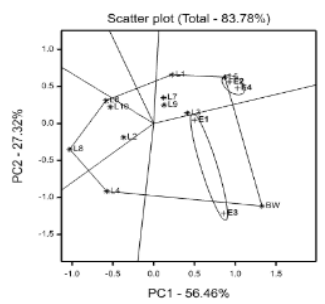

d. GGE biplot for seed per pod

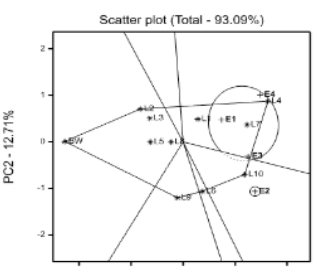

PC1 - 80.38\%

e. GGE biplot for hundred seed weight

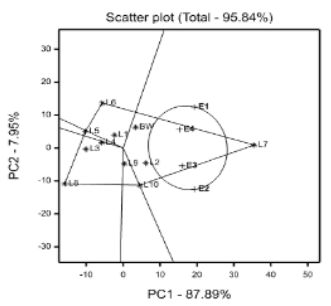

f. GGE biplot for grain yield

*Environments: E1= Syferkuil 2016, E2= Towoomba 2016, E3= Syferkuil 2017 and E4= Towoomba 2017; Genotypes: L1-L10, BW

Fig. 2: Mega environment and "which-won-where" biplot for (a) days to flowering (b) days to maturity, (c) pods per plant, (d) seeds per pod, (e) hundred seed weight and (f) grain yield of eleven tested genotypes across four environments

Towoomba was slightly higher during crop maturity (March) during both years (Figs. $1 \mathrm{~b}$ and d), genotypes L9 and L2 must have adapted better to warm temperature to quicken their maturity but the maturity of other lines at Syferkuil where the temperature was lower was delayed (Fig. $1 \mathrm{a}$ and c). These can be regarded to be adapted to the 
low-temperature location.

The local check BW produced more seeds per pod because of their small seed size than the other lines. The reason for this is that the improved varieties were bred and selected for large seed size to meet consumer preference. The elite cowpea breeding lines used in this study had large seeds $(>18 \mathrm{~g})$, whereas the check variety BW exhibited medium-sized seeds (15.1 to $17.3 \mathrm{~g}$ ) based on the classification by (Omogui et al. 2006). This finding implies that farmers will prefer to grow cowpea varieties that are large-seeded because they are not only more attractive and preferred by consumers as high premium seeds, but also cook faster and saves cooking time. Furthermore, varieties that expressed ' $\mathrm{G} \times \mathrm{Y} \times \mathrm{L}$ ' interaction were most affected by location and year, which implies that varietal selection should be based on the specific location where they are best adapted (Yan and Kang 2003; Addo-Quaye et al. 2011).

The mean grain yield at Towoomba was regarded as being very high because according to Sanjeev et al. (2018) IITA yield classification, "cowpea grain yield of 1500-2000 $\mathrm{kg} \mathrm{ha}^{-1}$ is regarded as high, and above $2000 \mathrm{~kg} \mathrm{ha}^{-1}$ as very high". Peksen (2007), Basaran et al. (2011) and Costa et al. (2017) reported that cowpea grain yield is influenced by the interactive effects of genotypes, years, and locations. Yield in cowpea is a function of many interacting components, such as the pods per plant, pod length, seeds per pod, and mean seed weight (Magashi et al. 2019; Gondwe et al. 2019). The grain yield produced at Towoomba was higher than that at Syferkuil, thus indicating that Towoomba is an ideal location for cowpea production compared to Syferkuil. Therefore, farmers will find this location more attractive and suitable for cowpea production. Lines L2 and 10 performed very well due to their better adaptation to the two locations, and this contributed to their success in grain production. Line performance was affected by season in that grain yield obtained at Syferkuil during 2016/17 season was lower, and was probably due to low moisture during the reproductive stage. Low moisture or water stress during the reproductive stage of cowpea is known to reduce the success of pollination, grain-filling, and yield (Freitas et al. 2017).

Based on the heritability categories established by Robinson et al. (1949), in this study, high heritability observed for seeds per pod, 100 -seed weight and grain yield imply these traits were less influenced by the environment which also indicates that selection for these characters would be effective, discernible and easy (Holland et al. 2003; Omogui et al. 2006; Gupta and Patel 2017).

GGE biplot is an important tool to identify the stability and best performing genotypes in different environments (Beyene et al. 2012). Results of this study indicate that L10, BW, L2, and L7 were very stable and won in grain yield and pods per plant in environments in both locations and years making them most adapted varieties for selection and cultivation in Towoomba and Syferkuil.

Lines were clustered into different mega-environments for different traits, thus indicating that environment greatly influenced these characters which means that performance of lines and their selection is environment-specific based. In other words, lines with traits grouped into one megaenvironment are suitable and adapted to that environment. The understanding of $\mathrm{G} \mathrm{X}$ E's effects on varieties is important for the identification of testing environments, and choice of germplasm (Leon et al. 2016). Yan and Tinker (2006) and Horn et al. (2018), reported that "when the test environments are clustered in one sector, it suggests that they did not differ significantly in their discriminating capacity so that deploying the genotypes in any of those environments would give similar results". Line L7 was the vertex genotype in mega-environment, E1, E2, E3, and E4 indicating that line L7 was very productive in grain yield at Syferkuil and Towoomba during the two years, outperforming lines L2, L10, and BW, which were associated with this mega-environment. According to Santos et al. (2017), the lines that fell into sectors that contained no environments, are not adapted for the test environments, therefore are considered unadapted. Line L7, which was ranked as the highest yielder across all environments, could be the best candidate line for production across sites and is regarded as the most adapted line.

According to Adewale et al. (2017), "PC1 scores greater than 0.0 detect the accessions with good adaptability and high performance while PC1 less than 0.0 discriminates the poorly adapted and poor yielding lines". Lines L9, L1, L2, L10, and L6 were left-side discriminated and were regarded unadapted for flowering trait because their PC1 scores were below 0.0. BW and other lines were placed on the right-side of the biplot, which represents adaptability and above-average performance. Lines L8, L5, L3, L6, L4, and $\mathrm{L} 1$ were below-average performance for grain yield and unadapted as they exhibited a PC1 scores below 0.0. The lines that achieved above-average performance were $\mathrm{BW}$, L10, L2 and L7 in increasing order. These lines had a 'PC1 score above 0.0 , and they were regarded as adapted', and high-yielding (Finlay and Wilkinson (1963). Therefore, the findings of this study show that Lines L7, L2, and L10 were adapted and exhibited higher grain yield than local check, BW.

\section{Conclusion}

The study indicated that the genotypes showed excellent agronomic performance in the study areas implying that the areas are conducive for cowpea production, however, the study showed that cowpea varieties varied in their performance in the two locations. Towoomba was a more productive location for cowpea production compared to Syferkuil. GGE plot revealed that L10, L2 and L7 were the most productive and adapted genotypes, and they can be released for commercial production in the two locations. Other good lines whose performances were promising at either location were adapted to that specific location, and 
those lines can further be evaluated in multi-locations for stability purposes.

\section{Acknowledgements}

The authors acknowledge the financial support received from the University of Limpopo, South Africa and National Research Foundation (NRF) of South Africa for conducting this study. We are grateful to both organizations.

\section{Author Contributions}

All the authors contributed relevantly in the execution of the study and preparation of the manuscript and subsequent revisions.

\section{Conflicts of Interest}

There was no conflict of interest from my institution or from other organizations neither from the stations that research was conducted.

\section{Data Availability}

The data used in this publication are original and has not been used eslwhere and the right has been transferred to $\mathrm{IJAB} / \mathrm{FS}$ to publish it with terms and conditions observed.

\section{Ethics Approval}

All ethical considerations were observed and there was no issues raised against the conduct of the study and publication of the data obtained from the study.

\section{References}

Addo-Quaye AA, AA Darkwa, MKP Ampiah (2011). Performance of three cowpea (Vigna unguiculata (L.) Walp) varieties in two agroecological zones of the central region of Ghana ii: Grain yield and its components. J Agric Biol Sci 6:34-42

Adewale BD, DK Ojo, M Abberton (2017). GGE Biplot application for adaptability of African yam bean grain yield to four agro-ecologies in Nigeria. Afr Crop Sci J 25:333-347

Adu GB (2018). Genetic diversity and population structure of earlymaturiing tropical inbred lines using SSR and SNP markers. PLoS One 14; Article e 0214810

Asiwe JAN (2017). Determination of Nutrient and Mineral Contents of Some Selected Cowpea Lines for Better Quality Trait Improvement. Book of Abstract, AGRI2017-Agriculture and Horticulture Conference, under subtitle-Food and Nutrients, 2-4 October, 2017, Park Inn, London, UK

Asiwe JAN (2009). Needs for assessment of cowpea production practices, constraints and utilization in South Africa. Afr J Biotechnol 8:5383-5388

Asiwe JNA, KA Maimela (2020). Yield and economic assessments of five cowpea varieties in cowpea-maize strip intercropping in Limpopo Province, South Africa. Intl J Agric Biol 25:27-32

Asiwe JAN, IB Oluwatayo, DN Asiwe (2020a). Enhancing Food Security, Nutrition and Production Efficiency of High-Yielding Grain Legumes in Selected Rural Communities of Limpopo Province South Africa, Vol. 1, p:169. WRC Report No. TT 829/1/20, Research Report and Capacity Building, South Africa
Asiwe JAN, IB Oluwatayo, DN Asiwe (2020b). Enhancing Food Security, Nutrition and Production Efficiency of High-yielding Grain Legumes in Selected Rural Communities of Limpopo Province, South Africa, Vol. 2. WRC Report No. TT 829/2/20, Production Guide, Training of Farmers and Cowpea Processing and Capacity Building, South Africa

Araújo LB, MD Pinheiro, LB Fiege, CH Bertini, JC Dovale (2019). Agronomic potential and genetic diversity of landraces of cowpea of the State of Ceará. Rev Caatinga 32:698-708

Asfaw A, F Alemayehu, F Gurum, M Atnaf (2009). AMMI and SREG GGE biplot analysis for matching varieties onto soybean production environments in Ethiopia. Sci Res Essays 4:1322-1330

Basaran U, I Ayan, Z Acar, H Mut, OO Asci (2011). Seed yield and agronomic parameters of Cowpea (Vigna unguiculata L.) genotypes grown in the Black Sea Region of Turkey. Afr J Biotechnol 10:13461-13464

Belane AK, JAN Asiwe, FD Dakora (2011). Assessment of $\mathrm{N}_{2}$ fixation in 32 cowpea (Vigna unguiculata L. Walp) genotypes grown in the field at Taung in South Africa, using $15 \mathrm{~N}$ natural abundance. Afr J Biotechnol 10:11450-11458

Beyene Y, S Mugo, T Tefera, J Gethi, J Gakunga, S Ajanga, H Karaya, R Musila, W Muasya, R Tende (2012). Yield stability of stem borer resistant maize hybrids evaluated in regional trials in East Africa. Afr J Plant Sci 6:77-83

Bressani R (1985). Nutritive value of cowpea. In: Cowpea: Research, Production and Utilisation, pp: 535-360. Singh SR, KO Rachie (Eds.). John Wiley \& Sons, Chichester, England

Comstock RR, HF Robinson (1952). Genetic Parameters their Estimation and Significance. In: Proceedingsof The sixth International Grassland Congress, pp:248-291. Washington DC, USA

Costa AFD, LSD Vale, ABD Oliveira, JFDB Neto, W Souto Ribeiro, GB Cardoso (2017). Evaluation of yield performance in cowpea genotypes (Vigna unguiculata). Aust J Crop Sci 11:308-312

DAFF (2011). Production Guideline for Cowpea, p:5. Department of Agriculture Forestry and Fisheries, Pretoria, South Africa

Eberhart ST, WA Russell (1966). Stability parameters for comparing varieties. Crop Sci 6:36-40

Fatokun CA, O Boukar, S Muranaka (2012). Evaluation of cowpea (Vigna unguiculata L. Walp) germplasm lines for tolerance to drought. Plant Genet Res 10:171-176

Fehr WR (1987). Principle of Cultivars Development, p:465. Macmillan Inc. New York. USA

Finlay KW, GN Wilkinson (1963). The analysis of adaptation in a plantbreeding programme. Aust J Agric Res 14:742-754

Freitas RMO, JLD Dombroski, FCL Freitas, NW Nogueira, JRS Pinto (2017). Physiological responses of cowpea under water stress and rewatering in no-tillage and conventional tillage systems. Rev Caatinga 30:559-567

Gondwe TM, EO Alamu, P Mdzinso, B Maziya-Dixon (2019). Cowpea (Vigna unguiculata (L.) Walp) for food security: An evaluation of end-user traits of improved varieties in Swaziland. Sci Rep 9; Article 15991

Gupta RP, SR Patel (2017). Heritability studies in cowpea [Vigna unguiculata (L.) Walp]. Trends Biosci 10:4751-4755

Hall AE (2012). Phenotyping cowpeas for adaptation to drought. Front Physiol 3; Article 155

Holland J, W Nyquist, G Cervantes-Martínez (2003). Estimating and Interpreting Heritability for Plant Breeding: An update, pp:175. Janick JJ (Ed.) Wiley \& Sons, Inc., New York, USA

Horn L, H Shimelis, F Sarsu, L Mwadzingenia, MD Laing (2018). Genotype-by-environment interaction for grain yield among novel cowpea (Vigna unguiculata L.) selections derived by gamma irradiation. Crop J 6:306-313

Jadhav BB, SD Khalfe, SP Birari (1991). Role of environmental factors in flowering and maturity of cowpea (Vigna unguiculata L. Walp). Ind J Plant Physiol 34:215-221

Leon N, J Jean-Luc, WE Jode, MK Shawn (2016). Introduction to a special issue on genotype by environment interaction. Crop Sci 56:2081-2089

Magashi AI, RS Shawai, A Muhammad, MB Ibrahim (2019). Genetic variability studies of some quantitative traits in cowpea (Vigna unguiculata L. [Walp]) under water stress. Afr J Plant Sci 13:25-33 
Nkhoma N, H Shimelis, MD Laing (2020). Assessing the genetic diversity of cowpea [Vigna unguiculata (L.) Walp.] germplasm collections using phenotypic traits and SNP markers. BMC Genet 21; Article 110

Omogui LO, MF Ishiyaku, AY Kamara, SO Alabi, SG Mohammed (2006). Genetic variability and heritability studies of some reproductive traits in cowpea (Vigna unguiculate (L.) Walp). Afr J Biotechnol 5:1191-1195

Owusu EY, R Akromah, NN Denwar, J Adjebeng-Danquah, F Kusi, M Haruna (2018). Inheritance of early maturity in some cowpea (Vigna unguiculata L. Walp) genotypes under rain fed conditions in northern Ghana. Adv Agric 2018; Article 8930259

Padulosi S (1993). Genetic Diversity, Taxonomy and ecogeographic survey of the wild relatives of cowpea (Vigna unguiculata (L.) Walpers). PhD Thesis, pp:20-45. University of Louvain La Neuve, Belgium

Peksen E (2007). Yield performance of cowpea (Vigna unguiculata L. Walp) cultivars under rainfed and irrigated conditions. Intl J Agric Res 2:391-396

Piebiep G, JM Moutinho-Pereira, TF Jorge, CM Correia, MR Oliveira, EAS Rosa, C António, H Trindade (2017). Cowpea (Vigna unguiculata L. Walp) metabolomics: Osmoprotection as a physiological strategy for drought stress resistance and improved yield. Front Plant Sci 8; Article 586

Robinson HF, RE Comstock, PH Harvey (1949). Estimates of Heritability and the degree of dominance in corn. Agron J 41:353-359

Sabaghnia N (2015). Identification of the most stable genotypes in multienvironment trials by using nonparametric methods. Acta Agric Sloven 105:103-110
Sanjeev KD, BR Mani, SA Desai, TK Nagarathna, RR Hanchina (2018). Review on characterization of cowpea germplasm in terms of distinctness, uniformity, stability and novelty for morphological, quality and yield attributing parameters. Intl J Curr Microbiol Appl Sci 7:1124-1139

Santos A, G Ceccon, EV Rodrigues, PE Teodoro, AM Correa, FE Torres, RF Alvarez (2017). Selection of cowpea genotypes for Mato Grosso do Sul via GGE biplot and linear regression. Biosci J 33:631-638

SAS Institute Inc (2013). SAS/ACCESS $® 9.4$ Edited by Song, Y. H., S. Ito and T. Imaizumi, 2013. Flowering time regulation: Photoperiod- and temperature-sensing in leaves. Trends Plant Sci 18:575-583

Summerfield RJ (1980). Effects of air temperature on seed growth and maturation in cowpea (Vigna unguiculata). Ann Appl Biol 88:437-446

Tarawali SA, BB Singh, M Peters, SF Blade (1997). Cowpea haulms as fodder. Adv Cowpea Res 1997:313-325

Thillainathan M, GC Fernandez (2002). A novel approach to plant genotypic classification in multi-site evaluation. HortScience 37:793-798

Timko MP, BB Singh (2008). Cowpea, a multifunctional legume. In: Genome Tropical Crop Plants, pp:227-258. Moore PH, R Ming (Eds.). Springer, Dordrecht, The Netherlands

Yan W, MS Kang (2003). GGE Biplot Analysis: A Graphical Tool for Breeders, p:288. Geneticists and agronomists. CRC Press, Boca Raton, Florida, USA

Yan W, NA Tinker (2006). Biplot analysis of multi-environment trial data: Principles and applications. Can J Plant Sci 86:623-645

Zakir M (2018). Review on genotype $\mathrm{x}$ environment interaction in plant breeding and agronomic stability of crops. J Biol Agric Healthcare $8: 14-21$ 